\title{
ПСИХОЛОГО-ПЕДАГОГІЧНЕ ПРОСВІТНИЦТВО БАТЬКІВ ДІТЕЙ РАННЬОГО ТА ДОШКІЛЬНОГО ВІКУ
}

\author{
Наукова доповідь загальним зборам НАПН України 19 листопада 2021 р.
} https://doi.org/10.37472/2707-305X-2021-3-2-1-8

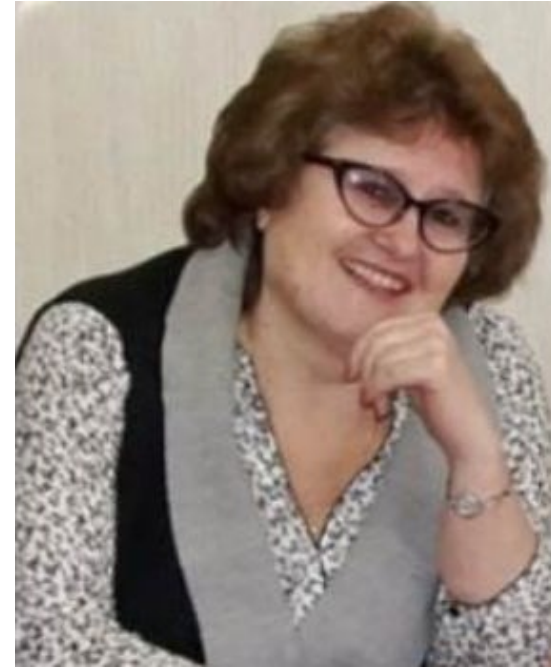

ПІРОЖЕНКО

Тамара Олександрівна

доктор психологічних наук, професор, член-кореспондент НАПН України, завідувач лабораторії психології дошкільника Інституту психології імені Г.С. Костюка Національної академії педагогічних наук України, м. Київ, Україна

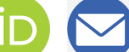

Анотація. Матеріали доповіді розкривають проблему педагогічного просвітниитва з позиції загального ставлення дорослих до дитинства. Рівень дитячо-батьківских відносин демонструє розвинену форму культурної самосвідомості дорослих, свідчить про цивілізовані форми взаємодіі мін поколіннями. Форма відповідальності дорослих перед дитинством демонструє як культурну самосвідомість дорослих, так $і$ культуру суспільства загалом. Порушено питання нормативноправової бази, що визначає взаємодію між освітніми закладами та батьками вихованців; описано наявні форми педагогічного просвітниит ва сучасного етапу розвитку суспільства та висвітлено інші актуальні питання означеної проблематики.

Ключові слова: психолого-педагогічне просвітничтво; дитина раннього та дошкільного віку; взаємодія між поколіннями; дитячобатьківські взаємини.

Проблема «Батьки та діти» стара як світ. Кожний з учасників загальних зборів Національної академії педагогічних наук України може представити свої роздуми та погляди з питань виховання дитини, оскільки ми не тільки фахівці, але й самі виступаємо учасниками дитячо-батьківських відносин.

Я хочу звернути увагу на проблему педагогічного просвітництва з позиції загального ставлення дорослих до дитинства, з позиції цивілізованої форми взаємин між поколіннями, а не тільки наявних у сфері дошкільної освіти форм та методів роботи педагогів з батьками вихованців. Тому узагальнений аналіз стосується ситуації всіх освітніх ланок - дошкільної, шкільної, професійної, освіти вищої школи, післядипломної освіти, тобто освіти дитини в контексті безперервного розвитку.

Термін просвітництво закріпився у науці після опублікування статті І. Канта «Відповідь на питання: що таке просвітництво?» (1784р.). Європейські інтелектуали того часу (Вольтер, Й.-Г. Гердер) проповідували соціальну та політичну ідею встановлення «царства розуму», заснованого на природному рівноправ'ї людей, політичній свободі і громадянській рівності; ставили за мету поширення знань: дати народу освіту і «просвітити» монархів відносно змісту «істинного» людського суспільства. Тим самим постулати просвітництва спричинили надлам старої феодальної організації та сприяли переходу від традиційного до індустріального суспільства.

Просвітництво - це цивілізаційно-культурна течія, ідеї якої справили такий величезний вплив на всі напрямки духовного життя європейського суспільства, що дали назву новій культурно-історичній добі. Аналіз наукових джерел свідчить, що питання просвіти батьків знайшли відображення в історії зарубіжної (Сократ, Аристотель, Сенека, Квінтіліан, Ж.-Ж. Руссо, Й.Г. Песталоцці, Ф.-А. Дістервег та ін.), 
вітчизняної (Г.С. Сковорода, В.О. Сухомлинський, К.Д. Ушинський та ін.) наукової думки. Історія просвітництва утверджує сучасну позицію про те, що здійснення педагогічного просвітництва передбачає врахування тенденцій розвитку стосунків між батьками й дітьми, їхніх ціннісних орієнтирів, особистісних якостей, особливостей впливу сім'ї на становлення особистості. Проте аналіз психолого-педагогічних джерел засвідчив, що єдиного й чітко визначеного поняття «педагогічне просвітництво» не існує. Педагоги зазвичай використовують термін «інформування батьків», метою якого $є$ надання певних знань про особливості становлення особистості дитини. Педагогічна ж просвіта передбачає наявність зворотного зв'язку, з'ясування позиції суб'єктів. Новизна цього змісту визначається поняттями «педагогізація батьків», «партнерство», «співробітництво», «співпраця», «взаємодія». Так, у «Педагогічному словникулексиконі» (за ред. А. Василюк, М. Танась) педагогізація батьків тлумачиться як «освітня діяльність, спрямована на постійне збагачення батьками педагогічних знань стосовно виховання дітей і молоді, а також різних аспектів функціонування сім'ї. Метою педагогізації $€$ безпосередня та опосередкована допомога батькам у формуванні їхньої педагогічної культури. Джерелами знань для батьків слугують: науково-популярна література, спеціальні журнали, посібники, радіо та телепередачі. Педагогізація батьків $€$ специфічною формою співпраці навчального закладу із сім'єю дитини» (Василюк \& Танась, 2013).

Коли ж саме доросле населення виокремило потребу в спеціальних знаннях щодо специфіки розвитку дитини, тобто знаннях, що визначають особливості навчання та виховання дітей?

Знаковим моментом, що демонструє сучасну позицію дорослих стосовно дітей, $є$ позиція Януша Корчака. Йому належать слова про те, що імена Песталоцці, Фребеля, Спенсера виблискують так само яскраво, як імена великих винахідників XIX століття, тому що вони відкрили більше, ніж незвідані сили природи, вони відкрили невідому половину людства - дітей. Після цього суспільство замислилось над питанням: що ми знаємо про дитинство? Яка прихована складність і непізнаність феномену дитинства визначає відносини дорослих з дітьми?

Уявлення про стан дитинства та осмислення особливостей і закономірностей зростання дитини з'явилися тоді, коли людство виділило період дитинства з життя людини, усвідомлюючи його як етап особливий, багато в чому відмінний від дорослого життя. Таке відкриття розпочалося з появи досліджень з історії дитинства, як в етнографічному контексті, так і в культурологічному. Вказаний напрям представляє власне культуру дитинства: середовище в широкому сенсі, оточення, культурні форми, які створюють дорослі для дітей. Саме в такому контексті проведено низку досліджень лабораторії психології дошкільника Інституту психології імені Г.С. Костюка НАПН України. Вони присвячені дитячим співтовариствам, особливостям їх взаємодії.

Досліджувана в лабораторії психології дошкільника проблематика, яка розкриває питання становлення культури дитинства:

- особливості розвитку взаємодії дитинидошкільника з дорослими та ровесниками в умовах дитячого садка та сім'ї;

- взаємодія дитячого садка та сім'ї з метою надання психотерапевтичної допомоги дітям, що постраждали від Чорнобильської аварії;

- гуманізація взаємодії дитини-дошкільника з дорослими та однолітками в умовах дитячого садка та сім'ї;

- становлення ціннісних орієнтацій дітей дошкільного віку в сучасному соціокультурному середовищі.

Реалізація та впровадження ідей з проведених досліджень завжди спиралася на психологопедагогічне просвітництво батьків вихованців. Кожна дослідницька тема тією чи іншою мірою пов'язана з розвитком дитини в умовах сім'ї відображала просвітницьку роботу науковців із батьками вихованців дошкільних освітніх закладів.

Друга складова частина досліджень дитинства - це природа дитини, прояв дитячої суті, форм діяльності самої дитини.

За весь час існування лабораторії психології дошкільника Інституту психології імені Г.С. Костюка НАПН України ії вчені розробляли найактуальніші питання, що розкривають природу дитини дошкільного віку. Це такі наукові теми:

- формування гуманних почуттів у дітей дошкільного віку в умовах суспільного та сімейного виховання;

- психологічні основи формування передумов навчальної діяльності дітей в умовах дошкільного закладу;

- міст і структура готовності дитини до школи;

- розвиток довільної поведінки дитини; 
- психологічне забезпечення розвитку здібностей у дошкільників у специфічно дитячих видах діяльності;

- особистісний розвиток дитини в різних інноваційних системах виховання;

- діагностика та корекція психічного розвитку дітей дошкільного віку;

- психологічні основи формування дошкільної зрілості;

- умови становлення особистісного потенціалу дитини-дошкільника;

- готовність дитини старшого дошкільного віку до навчання в умовах реформування української школи.

Розробленню цих актуальних питань присвятили свої наукові пошуки у 50-60-ті роки XX ст. Н. Балацька, Е. Косма, М. Вовчик-Блакитна, В. Котирло, О. Кульчицька. У 70-х роках XX ст. під керівництвом В.Котирло розпочинали свої наукові пошуки О. Проскура, Ю. Приходько, Л. Котлярова, С. Ладивір, С. Кулачківська, Т. Титаренко, С. Тищенко, О. Вовчик-Блакитна, О. Долинна. Сьогоденну наукову діяльність позиціонують Т. Піроженко, Л. Соловйова, І. Карабаєва, О.Хартман, Л. Токарєва, О. Федорчук.

Усі аспекти розроблених досліджень представлено у контексті умов розвитку дитини в дитячому садку та сім'ї, що так само продовжує традиції участі науковців у психолого-педагогічному просвітництві батьків вихованців закладів дошкільної освіти.

Ми щиро вдячні нашим колегам та вчителям, які склали вітчизняну історію наукових пошуків у галузі дитячої психології за великий період існування лабораторії психології дошкільника - майже за 75 років ії діяльності.

Аналіз досліджень розвитку дитини дає змогу стверджувати, що людство пройшло довгий шлях формування цивілізованого ставлення до періоду дитинства.

Правильні слова «гуманізм», «повага до особистості дитини», «уміння слухати і чути дітей» та інші сучасні гасла у сфері освіти самі собою не несуть відповіді на означене питання. Своєрідний історичний екскурс становлення та трансформації цивілізованого й гуманного ставлення до дитини у сфері ії̈ виховання демонструють роботи з історії феномену дитинства (Демоз, 2000). Зміна ставлення дорослих до дитини, динаміка культури дитячо-батьківських взаємин упродовж історії людства визначає саму модель виховання дітей. Починаючи з перших кроків відстороненого (IV-
XIII ст.) або нав'язливого/примусового (XVIIIст.) стилю дитячо-батьківських відносин людство поступово усвідомило потребу у формуванні таких взаємин з дитиною, які утверджують відмову від фізичних покарань, індивідуалізацію процесу виховання, створення умов для розвитку інтересів та здібностей дитини.

Так, виокремлено (Л. Демоз) шість різних домінантних моделей ставлення до дітей упродовж історії людства, у яких автор обгрунтовує вплив виховання в дитинстві через особливості дорослої людини, тим самим пов'язуючи виділені моделі виховання дітей з особливостями розвитку цивілізації в кожен період. Шість моделей стилю ставлення батьків до дитинства дослідник називає так (Демоз, 2000):

1. Інфантицидна (до IV ст. н.е.) - характеризується масовим вбивством дітей і насильством стосовно них. Стиль дітовбивства є вираженням страху батьків перед складностями догляду за дітьми. «Коли батьки боялися, - зазначає Л. Демоз, - що дитину буде важко виховати або прогодувати, вони звичайно убивали їі, і це впливало на дітей, які вижили» (Демоз, 2000). Страх був панівною емоцією у ставленні дорослого до немовляти.

2. Відсторонена (IV-XIII ст.) - характеризується відмовою від інфантициду у зв'язку з поширенням християнства і практикою передачі батьками дітей на виховання третім особам. Стиль став домінантним, коли «батьки почали визнавати в дитині душу, і єдиним способом уникнути прояву небезпечних для дитини дій було фактичне відмовлення від неї - ії відправляли до годувальниці, чи в монастир, чи в заклад для маленьких дітей, у будинок іншого знатного роду як слугу... чи оточували суворою емоційною холодністю вдома» (Демоз, 2000). Проєкції у цей період, як стверджує Л.Демоз, ще дуже сильні: вважаєтся, що дитина є повною зла, тому її треба увесь час бити та карати.

3. Амбівалентна (XIV-XVII ст.) - характеризується початком витіснення практики фізичних покарань. Дитині було дозволено влитися в емоційне життя батьків. Цей період характеризується подвійністю дитячо-батьківських відносин, оскільки дитина, з одного боку, залишається вмістилищем небезпечних проєкцій та дій дорослих, з іншого - уявляється дорослим м'яким воском, глиною, яким треба надати форми. Саме в цей період з'являється багато посібників з виховання дітей, посилюється культ Марії та дитини Ісуса. 
4. Нав'язлива/примусова (XVIII ст.) - характеризується початком розуміння потреб дитини, коли батьки намагалися тісніше зблизитися 3 дитиною, отримати владу над ії розумом і вже за допомогою цієї влади контролювати її внутрішній стан, гнів, потреби, волю.

5. Соціалізувальна (XIX - перша половина XX ст.) - характеризується масовим поширенням педагогічних знань, а також початкової і середньої освіти. Стиль взаємин, у якому виховання дитини полягає вже не стільки в оволодінні ії волею, скільки у їі тренуванні, спрямуванні на правильний шлях. Дитину вчать пристосовуватися до обставин, соціалізують. Цей стиль став підґрунтям всіх психологічних моделей двадцятого століття.

6. Допомагальна (із середини XX ст.) - характеризується індивідуалізацією процесу виховання, відмовою від фізичних покарань і рівноправними стосунками між батьками і дітьми. Стиль заснований на допущенні, що дитина краще, ніж батьки, знає свої потреби на кожній стадії розвитку. «...Створювати умови для розвитку їі інтересів ось що має на увазі цей стиль» - пише аналітик (Демоз, 2000). Дослідник зазначає, що поки небагато батьків з усією послідовністю випробували його на своїх дітях, тобто значною мірою цей стиль є проєктом на майбутне, а не відображенням реальної ситуації.

Можна стверджувати, що лише у XX ст. розпочалося усвідомлення проблеми розуміння дитини в процесі міжпоколіннєвої комунікації: не педагогічне тлумачення дитини як об'єкта, на який потрібно впливати, а дитини як самостійного суб'єкта, який має рівний з дорослим статус і цінність.

Зараз, у XXI ст., новоєвропейська філософія дитинства має два напрями, які поєднують тенденції звільнення (свободи) і захисту (опікування). Перший напрям - це утвердження у життя дитячих прав і свобод, дитяча соціалізація, яка йде від «Еміля» Ж.-Ж. Руссо, Декларації ООН про права дитини (1959), Конвенцію про права дитини (1989), багатьох законодавчих актів як в окремих країнах, так і на міжнародному рівні, введення ювенальної юстиції, що захищає права і свободи дітей.

Другий напрям - це концепція турботи (К. Гілліган, А. Рено, Дж. Агамбен), яка надає дитині статус не лише особи, але й індивідуальності, і конкретизується в ідеях етики піклування, турботи як нових перспектив стосовно філософського осмислення дитинства.

Вказані концептуальні напрями визначають зміст та способи поширення знань про розвиток дитини, а також зміст роботи з питань психологопедагогічного просвітництва батьків, які виховують дитину.

Ці концептуальні напрями не існують у житті в чистому вигляді. Ми і сьогодні можемо навести багато прикладів, які доводять, що і в наші дні $\epsilon$ відмова від дітей, кинуті діти при живих батьках, наявні навіть дітовбивчий, як це не страшно звучить, відсторонений, нав'язувальний, амбівалентний стилі взаємин батьків та дітей. Як стверджує статистика, кожна п'ята дитина в Україні зазнає сексуального насильства, що взагалі руйнує дитинство. Чи не є ці факти прикладами з IV, VI, XIII ст.? Чи це не приклади нашої суспільної дикості у XXI ст.? Чи це не привід для аналізу ситуації, яку можна назвати «гуманітарна прірва»?

Всі ці факти красномовно загострюють питання про рівень цивілізованої форми існування поколінь, рівень і форму культурної самосвідомості дорослих, коли вони представляють інтереси світу дитинства і тим самим позиціонують рівень особистісного розвитку.

Кожний з нас є особисто відповідальним за професійну культуру взаємодії з дитиною. Саме педагоги та психологи є носіями надії на утвердження цінності дитинства, формування ідей гуманістичного ставлення до дітей.

Саме в цьому аспекті стан розвитку дитинства $\epsilon$ ознакою культури суспільства загалом. Ставлення до дитинства та рівень дитячо-батьківских відносин демонструє розвинену форму культурної самосвідомості дорослих. Передбачувана форма відповідальності дорослих перед дитинством демонструє той факт, що суспільство представляє інтереси світу дитинства не лише заради дитинства, але і заради самої дорослості, демонструючи форму культурної самосвідомості дорослих і суспільства в цілому.

Який же маємо реальний стан в питаннях піклування та рівного доступу до освіти в українському суспільстві?

Сучасне українське суспільство має високий ступінь розроблення нормативно-правової бази, яка регулює ставлення держави до дитинства та відповідальності батьків щодо дітей. Ці питання відображено у Конституції України, Сімейному кодексі України, Цивільному кодексі України, Цивільному процесуальному кодексі України, 
законах України «Про охорону дитинства», «Про освіту», «Про дошкільну освіту».

Усі нормативно-правові акти України враховують Конвенцію про Права дитини (20 листопада 1989 р.) зі змінами, схваленими резолюцією 50/155 Генеральної Асамблеї ООН від 21 грудня 1995 р.), нагадуючи, що Організація Об'єднаних Націй в Загальній декларації прав людини проголошує право дитини на особливе піклування і допомогу, оскільки потребує «внаслідок ії̈ фізичної і розумової незрілості, спеціальної охорони і піклування, включаючи належний правовий захист як до, так і після народження».

Успіхи, досягнуті українськими вченими в галузі збереження життя дитини, ії̈ психічного, фізичного й соціального розвитку, організації освітньої діяльності, не співмірні з тим, наскільки ці ефективні методи лікування, гігієни, навчання, виховання і психологічного супроводу доступні для неповнолітніх громадян нашої держави.

В Україні за роки ії незалежності чисельність дитячого населення зменшилась майже вдвічі. «Сьогодні статистика невтішна. За роки незалежності країни дитяче населення зменшилось майже в два рази і сьогодні становить 7,6 млн», зазначив Уповноважений Президента України 3 прав дитини М. Кулеба.

Нині Україна посідає 186 місце у світі за показником народжуваності. Майже 106 тис. дітей, або 1,5 \% усього дитячого населення країни, живуть і виховуються в інтернатах, але тільки 8 \% з них $\epsilon$ сиротами - решта 92 \% мають батьків. Кожні три дні 250 дітей потрапляють до інтернатних закладів переважно через бідність і неспроможність батьків надати необхідні послуги для дитини. Щонайменше 600 тис. дітей проживають у неблагополучних родинах, і вони, по суті, стоять у черзі на потрапляння до інтернатних закладів.

До того ж сьогодення додало проблем травмованого дитинства. В Україні, де йде неоголошена війна, де відбуваються активні бойові дії, природні й соціальні катаклізми, де діти страждають від голоду, а також наявні потужні міграційні процеси, існує нагальна потреба в детальнішому розгляді концепції дитинства, головною філософською ідеєю якої є етика турботи та піклування. Факти сьогодення вказують на те, що станом на 26 лютого 2021 р. виконавчими органами міських, сільських, селищних рад, райдержадміністраціями, військово-цивільними адміністраціями прийняті рішення про надання статусу близько 25 тис. дітям, з-поміж яких: 76 - внаслідок отри- мання дітьми поранення, контузії чи каліцтва; 1 внаслідок того, що дитина зазнала фізичного насильства; понад 24 тис. - внаслідок того, що діти зазнали психологічного насильства (Донецька обласна державна адміністрація. Служба у справах дітей Донецької облдержадміністрації, лист від 19 лютого 2021 р. № 58).

Які сучасні тенденції демонструє суспільство у вирішенні цих питань?

Як відомо, обсяги доступності психологічної і медичної допомоги, забезпечення належних педагогічних, гігієнічних та екологічних умов повноцінного розвитку дитини раннього та дошкільного віку визначаються:

- політичними настановами стосовно прав дітей;

- усвідомленням політичних і державних діячів, який рівень відводиться задоволенню нужд дитячого населення в загальній системі фінансових, економічних та майнових пріоритетів;

- мірою уваги до проблеми охорони дитинства в суспільстві;

- діяльним, а не обіцяльним підходом до розподілу сукупних ресурсів у державі;

- культурою кожної людини стосовно дитинстBa.

Кожний з цих аспектів визначає характер наявних форм дитячо-батьківских стосунків в сім'ї та рівень розвитку дитини в освітніх закладах.

Яка ж ситуація в освітньому розвитку дітей раннього і дошкільного віку? Незважаючи на проголошене державою гасло про доступність кожної дитини до освіти, на сьогодні ми маємо таку ситуацію: за даними Інституту освітньої аналітики на кінець 2020 р. мережа закладів освіти, що забезпечують здобуття дошкільної освіти дітьми відповідного віку становила понад 15,3 тис. закладів (місто - понад 6,1 тис.; село - більше 9,2 тис.). У них здобувають дошкільну освіту понад 1,1 млн. (місто - 884,7 тис.; село - 265,8 тис.) дітей.

Отже, майже 30 \% дітей дошкільного віку не мають можливості відвідувати освітній заклад, зокрема серед населення сільської місцевості це майже половина дітей дошкільного віку.

Для батьків, діти яких відвідують заклади дошкільної освіти, психолого-педагогічне просвітництво здійснюється у формах педагогічної взаємодії педагогів з батьками в освітньому процесі. Ця робота посилюється у зв'язку із прийнятим у січні 2021 р. оновленим Стандартом дошкільної освіти, у якому вперше прописано різні форми участі батьків в 
освітньому процесі, управлінні та громадському самоврядуванні закладу дошкільної освіти. Розроблені авторами Стандарту дошкільної освіти (науковий керівник робочої групи МОН України Т.О. Піроженко) обгрунтовані рекомендації спрямовують зміст, форми роботи та взаємодію фахівців дошкільної освіти та батьків вихованців. Саме культура комунікації освітян дошкільної галузі з батьками вихованців закладає вкрай важливий для суспільства досвід довіри між сім'єю та освітніми інституціями, досвід, що потрібний кожному впродовж життя.

Розуміючи необхідність підвищення ролі батьків в освітньому процесі, тобто актуалізації їх суб'єктності в освіті та збільшення правових та організаційних засад у функціонування і розвитку системи освіти на ранніх етапах розвитку дитини, автори Стандарту дошкільної освіти (МОН України, 2021) привнесли суттєве доповнення в зміст документу, зокрема у визначенні характеристики компетентностей як освітнього результату та визначенні участі батьків у їх формуванні (МОH України, 2021).

Тим самим Стандарт дошкільної освіти спрямовує увагу дорослих на актуальну для сучасного етапу розвитку дошкільної освіти в Україні ідею солідарної відповідальності держави, громади, родини, фахівців педагогічної освіти й інших професій, причетних до піклування, догляду та розвитку дітей раннього і дошкільного віку. Основними формами педагогічного просвітництва батьків у закладах дошкільної освіти є: відвідування сім'ї, індивідуальні бесіди, групові консультації, батьківські збори, лекції для батьків, куточки для батьків, тематичні виставки, дні відкритих дверей тощо. Поряд із традиційними застосовуються і нетрадиційні, інноваційні форми роботи з батьками. Їх різноманіття залежить від креативності педагогічного колективу і бажання втілювати ці форми у життя. Прикладом нетрадиційних форм роботи з батьками можуть бути вернісажі, спільне оформлення альбомів, спільна цікава справа тощо. До інноваційних форм відносимо: звукові листи; бібліотеки відеоматеріалів з різних проблемних питань; школи взаємодопомоги; електронні мінібібліотеки; інтернет-сайти для батьків; демонстрації фільмів; тренінги; 10-12-хвилинні стрічки, що ілюструють конкретні ситуації, взяті з повсякденного спілкування батьків та дітей; презентації і прем'єри книг; «interaction room» та буктрейлери. У світлі сьогодення новим трендом у роботі вихователів з батьками став буктрейлер. Буктрей- лер - особливий вид книжкової реклами, один із засобів просування педагогічного видання до батьків, короткий відеоролик, що створює візуальний образ книги, кліп за їі змістом. Основне завдання буктрейлера - яскраво й образно розповісти про твір, зацікавити, заінтригувати читача, спонукати до читання літератури, що розкриває питання розвитку дітей.

Але виникає питання щодо батьків, діти яких не відвідують освітні заклад. Чи існують для таких родин розповсюджені форми психологопедагогічного просвітництва? Відповідь: системних форм роботи не існує.

Тому важливим рішенням учасників загальних зборів Національної академії педагогічних наук України було $б$ створення інформаційної освітньої/просвітницької платформи для батьків, діти яких не відвідують заклади дошкільної освіти.

До того ж у наявній траєкторії безперервного розвитку дитини раннього та дошкільного віку в нормативно-законодавчих документах втрачається статус сімейного/родинного виховання. Визначеними для дошкільної галузі освіти є такі форми здобуття дошкільної освіти: інституційна та індивідуальна. Інституційною вважається очна, дистанційна та мережева форми освіти. Очна форма здобуття освіти - це спосіб організації навчання здобувачів освіти, що передбачає їхню безпосередню участь в освітньому процесі; дистанційна форма здобуття освіти - це індивідуалізований процес здобуття освіти, який відбувається в основному за опосередкованої взаємодії віддалених один від одного учасників освітнього процесу у спеціалізованому середовищі, що функціонує на базі сучасних психолого-педагогічних та інформаційно-комунікаційних технологій; мережева форма здобуття освіти - це спосіб організації навчання здобувачів освіти, завдяки якому оволодіння освітньою програмою відбувається за участю різних суб'єктів освітньої діяльності, що взаємодіють між собою на договірних засадах.

Зважаючи на сучасні виклики гуманізації освіти дітей, виклики епідеміологічного характеру та збільшення ролі дистанційних форм навчання, що вочевидь посилює роль та активність батьків в освітньому процесі, важливим виступає психолого-педагогічне просвітництво всіх батьків, які виховують дитину раннього та дошкільного віку, з питань збереження та розвитку потенціалу вікових досягнень періоду дитинства. Актуальним $\epsilon$ розуміння специфічно дитячих розвивальних видів діяльності. Це насамперед гра; рухова діяль- 
ність; спілкування; образотворча (ліплення, малювання, аплікація, конструювання) та художньопродуктивна (музична, театральна) діяльність; пізнавально-дослідницька, побутово-господарська діяльність (праця).

Важливим для наукового та юридичного обгрунтування виступає питання про зміст поняття «батьківське піклування». Аналіз законів України «Про освіту», «Про дошкільну освіту», Положення про заклад дошкільної освіти та інші документи свідчить про те, що поняття «батьківське піклування» зустрічається тільки в питаннях соціального захисту дітей. На це вказують норми та положення законів України «Про забезпечення організаційно-правових умов соціального захисту дітейсиріт та дітей, позбавлених батьківського піклування» та «Про органи і служби у справах дітей та спеціальні установи для дітей», Порядку провадження органами опіки та піклування діяльності, пов'язаної із захистом прав дитини, затвердженого постановою Кабінету Міністрів України від 24 вересня 2008 р. № 866. Усі ці закони про соціальний захист дітей спрямовують увагу дорослих на вже набутий дитиною статус сироти, демонструючи наявний у суспільстві феномен соціального сирітства. Але тільки 8 \% із загального числа дітей, що мають означений статус, є сиротами решта $92 \%$ мають батьків. Тому так важливо сприяти сучасним науковим дослідженням щодо визначення сучасного змісту категорій «батьківське піклування», «сімейне виховання», «родинне виховання», узгоджуючи сучасні рольові функції членів родини із законами України «Про охорону дитинства», «Про освіту», «Про дошкільну освіту», «Про загальну середню освіту», Сімейним Кодексом, Цивільним Кодексом, Конституцією України. Актуальними залишаються дослідження з етнопедагогики та історії народних традицій освіти дітей, їх оновлення та розвиток у нових умовах XXI ст. для висвітлення найкращих традицій родинного виховання.

Актуальною та науково виваженою могла б бути стратегія проведення досліджень, які відображають тенденції світової науки щодо вивчення вікових особливостей людини на різних етапах онтогенезу. Сучасні світові наукові тенденції в оцінках вікової періодизації утверджують збільшення часової перспективи підлітків, юнацтва, молоді, і це змінює різні аспекти соціальнорольових функцій дорослих стосовно проблем освіти й виховання молодого покоління. Коло наукових досліджень міжпоколіннєвої взаємодії та множинності її репрезентацій в галузі освіти на етапах розвитку дитини раннього, дошкільного, підліткового, юнацького віку було $б$ визначним та перспективним напрямом діяльності Національної академії педагогічних наук України. Враховуючи безперечну роль сім'ї у формуванні фізичного, психічного здоров'я та своєчасної соціалізації дитини, а також розуміння значущості сім'ї як дієвого, моделювального, соціального, комунікативного, культурного інституту в загальній структурі державотворення, необхідно створити Інститут сім'ї та дитини, який транслюватиме вирішення питань взаємодії між поколіннями та зміну функцій дорослих на різних етапах зростання людини.

Очевидним є питання деформації і навіть руйнування традицій підготовки молодого покоління до функцій батьківства. Про це вказує зниження на всіх ланках освіти їі гуманітарного складника. Процентне співвідношення таких предметів, як «Етика», «Естетика» «Психологія», «Історія культури та мистецтв», тобто предметів, що орієнтують на формування ціннісних орієнтацій людини та взаємин між людьми, майже катастрофічне. Дисбаланс між загальноосвітніми гуманітарно орієнтованими та вузькопрофільними предметами вказує на конфліктні протиріччя між гаслами суспільства про духовний розвиток молоді та змістом освіти. Так, наприклад, у робочих планах підготовки фахівців технічного профілю із 40 обов'язкових предметів рівня «бакалавр» гуманітарний складник представляють предмети «українська», «англійська» мова». Водночас вибірковими для студіювання визначаються «філософія», «релігієзнавство», «культура та історія України», «політологія». Враховуючи реальний стан вибору предметних модулів, за відсутност викладацького складу певного профілю найкращим результатом залишається «політологія». Чи не пояснює прірва гуманітарних знань у свідомості молоді поширення в суспільстві такого феномену, як чайлдфрі (англ. cildfree, дослівно «вільний від дітей») - субкультура та ідеологія що утверджує постулат про відсутність дітей як привілею розвиненого соціуму? Аналогічно деструктивним феноменом сучасного суспільства $\epsilon$ явище «чайлдхейту» (анг. childhate - дослівно «дитиноненавісники»), тобто наявність людей, яких дратують діти, навіть думки про дітей, їх дратують дитячий сміх, ігрова активність, плач. Крайня відчуженість та розрив міжпоколіннєвої взаємодії та міжпоколіннєвого розуміння насто- 
рожує та руйнує перспектви гуманітарного розвитку суспільства.

Визначення та реалізація заходів з підготовки молоді до батьківства шляхом посилення ролі гуманітарних знань у процесі підготовки майбутніх фахівців, проведення факультативів, тематичних уроків, тренінгів тощо з учнями старших класів загальноосвітніх шкіл $€$ нагальною потребою суспільства. Серед важливих питань цього спрямування $€$ й потреба запровадження в закладах вищої освіти для студентів соціономічних спеціальностей навчальних курсів «Психологія відповідального батьківства», «Партнерська взаємодія з батьками вихованців в закладах дошкільної освіти: психолого-педагогічні засади та успішні комунікативні практики». Зміст зазначених вище курсів і тренінгів важливо впроваджувати в центрах професійного розвитку педагогів (ЦПРП) та в закладах післядипломної педагогічної освіти з метою надання освітніх послуг спільноті педагогів закладів дошкільної освіти, яка потребує навчання із зазначеного питання. Впровадження необхідної професійної підготовки спеціалістів дошкільної галузі сприяє поширенню культури комунікації освітян з батьками вихованців.

Реальну практику цілеспрямованого формування системної батьківської участі в освітньому процесі реалізовано у проекті «Впевнений старт» для дітей молодшого, середнього, старшого дошкільного віку. Вчені лабораторії психології дошкільника Інституту психології імені Г.С. Костюка НАПН України (Т.О. Піроженко, О.Ю. Хартман) спільно з науковцями Інституту проблем виховання НАПН України (Н.В. Гавриш, В.В. Рагозіна), представницею кафедри дошкільної освіти Маріупольського державного університету (О.Г. Брежнєва) та іншими фахівцями дошкільної освіти створили освітній проект «Впевнений старт» (наук. кер. Т.О. Піроженко), у якому навчально-методичний матеріал розроблено не тільки для педагогів та дітей молодшого, середнього, старшого віку, але, що важливо, для батьків вихованців. Освітній проект «Впевнений старт» втілює ідеї та напрацювання досвіду особистісно-орієнтованої моделі життєдіяльності дітей старшого, середнього та молодшого дошкільного віку та відповідає положенням Концепції Нової української школи (online платформа vstart.com.ua). Розробка та впровадження освітнього проєкту «Впевнений старт» включає освітню програму для дітей молодшого, середнього та старшого дошкільного віку, комплект навчально-методичного забезпечення для дітей, педагогів та батьків вихованців, методичний супровід та підтримку процесу імплементації проекту відео- та аудіоконтентом, що представлений матеріалами інтернет-ресурсу. Психологопедагогічні розробки освітнього проекту «Впевнений старт» для дітей старшого дошкільного віку та для дітей середнього дошкільного віку презентовано на X і XI Міжнародних виставках «Інноватика в сучасній освіті» у 2018 та 2019 рр. та відзначено золотою медаллю і знаком «Національне визнання наукових досягнень».

Цей досвід спільної взаємодії між педагогами та батьками вихованців має вагомі освітні результати. Так, психологічне обстеження дітей старшого дошкільного віку в групах тих освітніх закладів, у яких впроваджено освітню систему «Впевнений старт», визначає високий рівень досягнень за всіма напрямами, які представлено у Стандарті дошкільної освіти (середня оцінка за шкалою 1-5 у напрямі «Дитина в соціумі» - 4,53; напрямі «Гра дитини» - 4,16; напрямі «Дитина в природному довкіллі» - 4,29; напрямі «Дитина у світі культури» - 4,09; напрямі "Дитина в сенсорнопізнавальному просторі» - 4,22; напрямі «Мовлення дитини» - 4,19).

Співтворчість вчених Національної академії педагогічних наук України та практиків дошкільної галузі освіти має потужну базу для подальших досліджень теоретичного й прикладного спрямування, останнім з яких $€$ проблематика готовності дитини дошкільного віку до систематичного навчання в умовах реформування української школи, яка обґрунтовує вирішення питань наступності освіти дитини впродовж життя.

Узагальнюючи роздуми та висловлені пропозиції, сподіваюсь, що учасники загальних зборів НАПН України підтримають стратегічно важливі твердження щодо проблеми психологопедагогічного просвітництва батьків вихованців освітніх закладів, які впливатимуть на процес подальшої інтеграції медичних, психологічних, педагогічних знань про специфіку розвитку дитини раннього та дошкільного віку, що у майбутньому $є$ запорукою збереження його самоцінності на подальших етапах безперервної освіти.

Психолого-педагогічне просвітництво батьків утверджує позицію про те, що дитинство - це окремий, важливий, самоцінний (якщо не вирішальний) період фізичного і духовного розвитку людини, період соціального становлення через досвід взаємодії з навколишнім світом та природою. Збагачувати знання про особливості розвитку 
людини на етапі дитинства, створювати умови для реалізації потенціалу вікових можливостей дитини, примножувати сучасні форми комунікації із сім'єю, сприяти розповсюдженню гуманітарних традицій родинного виховання та підготовки молоді до функцій батьківства в нових умовах XXI століття $є$ завданням психолого-педагогічного просвітництва батьків дітей раннього та дошкільного віку.

\section{СПИСОК ВИКОРИСТАНИХ ДЖЕРЕЛ}

Василюк, А., \& Танась, М. (2013). Педагогічний словник-лексикон (українсько-англо-польський). Вид. 2ге, уточ. й доповн. Ніжин: ПП Лисенко М.М.

Демоз, Л. (2000). Психоистория (А. Шкуратов, пер. с англ.). Ростов на Дону: Феникс.

Закон України «Про дошкільну освіту». (2001, 11 липня). https://zakon.rada.gov.ua/laws/show/2628-14

Косенчук, О.Г., Новик, І.М., Венгловська, О.А., \& Куземко, Л.В. (упоряд.). (2021). Державний стандарт дошкільної освіти: особливості впровадження : навчально-методичний посібник. Харків: Ранок.

Міністерство освіти і науки України (2021, 12 січня). Про затвердження базового компонента дошкільної освіти (Державного стандарту дошкільної освітu) нова редакція (33). https://bit.ly/3EGfTUC

Новик, І.М., \& Ткаченко, К.О. (2017). Педагогічне просвітництво батьків. Молодий вчений, (12), 417-420. https://elibrary.kubg.edu.ua/id/eprint/23816/

Піроженко, Т.О., \& Хартман, О.Ю. (2014). Виховуємо дитину - зростаємо як батьки : навчальнометодичний посібник. Тернопіль: Мандрівець.

Піроженко, Т.О., Ладивір, С.О., ВовчикБлакитна, О.О., Карабаєва, І.І., Карасьова, К.В., Пісарєва, О.В., Гуменюк, Г.В., Мельник, І.С., Гурковська, Т.Л., \& Токарєва, Л.Д. (2012). Становлення внутрішньої картини світу дошкільника: монографія. (Т.О. Піроженко, ред.). Кіровоград: Імекс-ЛТД. https://lib.iitta.gov.ua/1604/

Піроженко, Т.О., Соловйова, Л.І., Ладивір, С.О., Карабаєва, І.І., Хартман, О.Ю., Федорчук, О.І., \& Токарєва, Л.Д. (2016). Ціннісні орієнтації дитини у дорослому cвimi : навчально-методичний посібник. Київ: Видавничий Дім «Слово». https://lib.iitta.gov.ua/710118/

\section{THE PSYCHOLOGICAL AND PEDAGOGICAL ENLIGHTENMENT OF EARLY AND PRESCHOOL-AGE CHILDREN'S PARENTS \\ Scientific Report to the General Meeting of the National Academy of Educational Sciences of Ukraine, November 19, 2021}

Tamara Pirozhenko

DSC in Psychology, Professor, Corresponding Member of NAES of Ukraine, Head of the Laboratory of Psychology of the Preschooler, G.S. Kostiuk Institute of Psychology of the National Academy of Educational Sciences, Kyiv, Ukraine

Abstract. The problem of pedagogical enlightenment from the position of the general attitude of adults to childhood is presented. The level of child-parent relations shows a developed form of cultural self-awareness of adults, indicates a civilized form of interaction between generations. The state of responsibility of adults to childhood demonstrates both the cultural self-awareness of adults and the society's culture as a whole. The report reveals the regulatory framework that determines the interaction between education institutions and parents of pre-schoolers; the modern forms of pedagogical enlightenment existing at the present stage of society's development are described; other urgent issues of the mentioned problem are enlightened.

Keywords: psychological and pedagogical enlightenment; early and preschool-age children; interaction between generations; child-parent relations. 